\title{
Obituary: Graeme Donald Marshall (30 April 1934-7 January 2015)
}

\author{
Christopher Cordner ${ }^{1}$ • Patrick Hutchings ${ }^{1}$
}

Published online: 5 October 2015

(C) Springer Science+Business Media Dordrecht 2015

Graeme Marshall was for many years a reader in philosophy at the University of Melbourne. He was born in 1934 at Hamilton, New Zealand. His first degree was an MA from the - now extinct - University of New Zealand - which he attended Victoria University College, Wellington. He moved to Melbourne where he completed his $\mathrm{PhD}$. Graeme Marshall's father was a minister of the Presbyterian Church, and Graeme was for a time reading for Holy Orders in that denomination: he described himself as a 'Scotto Catholic'. The first professor of philosophy at VUC, appointed in the mid 1950s, was the Rev'd G.E. Hughes, an Anglo Catholic. I, a Roman Catholic, had just been appointed Junior Lecturer in Philosophy (1954) and G.D.M. attended my lectures on baby logic and Russelian logic in 1954, without - as far as I know-complaint. Despite his immersion in a religious soup at VUC, Marshall became a nonbeliever, a Humeian sceptic. In the conduct of his life, Graeme Marshall was a polished stoicespecially when he succumbed to throat cancer, which he survived for many years.

Graeme Marshall married three times to Brenda, Eva and Yasmin; and his children Adrian, Holly and Sam, and grandchildren Milo, Jude, Toby and Thai, survive him.

Marshall's philosophical acumen was widely respected, and he attended seminars at St. Edmund Hall in the University of Oxford. His contributions to the topic of 'weakness of will' - (in which he did not believe) are acknowledged by the Hall's principal (1982-1996) Justin Gosling in his book Weakness of the Will (1990). Marshall wore the Teddy Hall scarf and tie on high days. In his retirement year, the college gave him a grand sendoff dinner: the University of Melbourne gave him a weekend of papers en hommage. Marshall also lectured at Kings College in the University of London for at least two sessions in the late 1980s.

Marshall joined the Melbourne department in 1965 and retired at the end of 1999. He was an acknowledged master of the writings of Ludwig Wittgenstein, when

Patrick Hutchings

sophia@philosophy.unimelb.edu.au

Christopher Cordner

ccordner@unimelb.edu.au

1 University of Melbourne, Melbourne, Australia 
Wittgenstein was a significant influence in the Melbourne department, with Camo Jackson, Douglas Gasking, Don Gunner and Kevan Presa. Graeme Marshall was a fine teacher, and perhaps his greatest gift as a teacher was to infuse into his students a vital sense of philosophy as a conversational practice which might then inform their lives beyond strict philosophy as well as within it. Right around Australia, Marshall was a prominent and respected philosophical presence for more than 30 years. His contributions at conferences and other philosophical gatherings across that time were invariably acute, clear and precise and always offered in a collaborative and generous spirit.

A connoisseur of wine, food and ceremony, Marshall was the first - and last manciple to the Philosophy Department at the University of Melbourne. This mediaeval rôle had to do-I think - with his being on the wine committee of Staff Club of the University of Melbourne, an institution of which he was a life member. Marshall is remembered with affection by his colleagues for his urbanity, brilliant philosophical conversation, and for somewhat eighteenth century or Oxonian turns of phrase. In this stoicism and style, he modelled himself on the philosopher whose view of life he most admired, le bon David.

20 July 2015 